\title{
EVALUATION OF ANTICANCER ACTIVITY OF CUCUMIS CALLOSUS AGAINST EHRLICH'S ASCITES CARCINOMA BEARING MICE
}

\author{
SIVA PRASAD PANDA*, RAJSEKHAR REDDY A, UTTAM PRASAD PANIGRAHY
}

Department of Pharmacology, KL College of Pharmacy, KLEF Deemed to be University, Vaddeswaram, Guntur, Andhra Pradesh, India. Email: sivaprasad.panda@kluniversity.in

Received: 21 May 2018, Revised and Accepted: 30 June 2018

\section{ABSTRACT}

Objective: Our previous research isolated Cucurbitacin B (CuB) and ebenone leucopentaacetate (ELP) from methanolic fruit extract of Cucumis callosus (MFCC). The fruits of $C$. callosus (Rottl.) Cogn. (Family: Cucurbitaceae) plant have been traditionally used for antioxidant, anti-inflammatory, and antidiabetic actions. The objective of this research was to evaluate in vitro and in vivo anticancer effect of MFCC on Ehrlich Ascites Carcinoma (EAC) cell lines.

Methods: In vitro anticancer assay of MFCC and standard drug, 5-fluorouracil (5-FU) was evaluated using Trypan blue and 3-(4, 5-dimethylthiazolyl)-2, 5-diphenyl tetrazolium bromide methods. In vivo anticancer activity of MFCC and 5-FU was also performed after $24 \mathrm{~h}$ of EAC cells ( $2 \times 106$ cells/ mouse) inoculation based on toxicity study for 9 consecutive days. The activity of the extract was assessed by the study of tumor volume, tumor weight, viable and non-viable cell count, hematological parameters, and biochemical estimations.

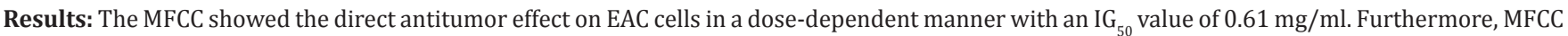
$(350 \mathrm{mg} / \mathrm{kg})$ exhibited significant $(\mathrm{p}<0.01)$ decrease in tumor volume, tumor weight, and viable cell count of EAC-treated mice. Hematological profile, biochemical estimation assay significantly $(\mathrm{p}<0.01)$ reverted to normal level in MFCC, and 5-FU treated mice.

Conclusion: The anticancer activity of fruits of $\mathrm{C}$ callosus is may be either due to the presence of CuB or/and ELP as phytoconstituent and the activity is comparable to standard drug 5 -FU.

Keywords: Cucumis callosus, Anticancer, Ehrlich Ascites Carcinoma cell lines.

(C) 2018 The Authors. Published by Innovare Academic Sciences Pvt Ltd. This is an open access article under the CC BY license (http://creativecommons. org/licenses/by/4. 0/) DOI: http://dx.doi.org/10.22159/ajpcr.2018.v11i10.27439

\section{INTRODUCTION}

Cancer is one of the largest causes of mortality in the world in the $20^{\text {th }}$ century and Hussain et al. 2012 explored the pattern and trends of cancer in Odisha. A total of 74,861 cancer inpatients were registered at Acharya Harihar Regional Cancer Center, Cuttack, Odisha, for the years 2001-2011 [1,2]

Nature is always the great contributor toward this goal. Plants, vegetables, and herbs have been accepted as a source of cancer-preventing agent. Most of the pharmaceutical sectors throughout the globe carried out research to find a lead compound from the traditional systems of medicine which can block the development of cancer in a human $[3,4]$

Most of the cancer chemotherapeutic agents are associated with toxicity toward normal cells and tissues. Optimal dosing of cancer chemotherapeutic agents is often limited because of severe bone marrow depression as toxicity. It is a continuing challenge to design a therapy that is safer, effective, and selective $[5,6]$. Modern cancer biology focused on new anticancer drug development that may act in different mechanisms. In fact, those compounds having cytotoxic or cytostatic ability against cancer cells show a potential anticancer activity [7].

Evidence suggests that phytochemicals from fruits and vegetables may play an important role in reducing diabetes and cancer $[8,9]$. The proposed plant part in this study is fruits of Cucumis callosus (Rottl.) Cogn. (Cucurbitaceae). Fruits are oval or elliptical in shape and having bitter pericarp with numerous small seeds (Fig. 1) [10,11]. Tribal peoples of Balasore and Baripada district, Odisha, and East Midnapore district of West Bengal use fruits of $C$. callosus as a vegetable, during worship and for curing diabetes, epilepsy, inflammatory disorders, and diarrhea [12]. Ehrlich Ascites Carcinoma (EAC) cells are experimental tumor models used worldwide in cancer research. In 1907, Paul Ehrlich discovered this tumor in the mammary gland of a white mouse, and the tumor was named after him. It is a rapidly growing carcinoma with very aggressive behavior and is able to grow in almost all strains of mice. In ascites form, it has been used as a transplantable tumor model to investigate the antitumor effects of several substances $[13,14]$.

This research evaluated the anticancer activity of $C$. callosus against Ehrlich's ascites carcinoma bearing mice. Our previous research isolated Cucurbitacin B (CuB) and ebenone leucopentaacetate (ELP) from methanolic pericarp extract of $C$. callosus [15]. CuB inhibits the growth of human malignant cells, both in vitro and in vivo, and has been shown to be effective against breast cancer, head, and neck squamous cell carcinoma, pancreatic cancer, hepatocellular carcinoma, osteosarcoma, and myeloid leukemia $[16,17]$. Consequently, natural and semisynthetic CuBs are proposed as a promising source for the development of new drugs for the prevention and treatment of various cancers. The objective of the research was to evaluate in vitro and in vivo anticancer effect of fruits of $C$. callosus on EAC cell lines.

\section{METHODS}

Drugs and chemicals

5-fluorouracil (5-FU), 3-(4, 5-dimethylthiazol-yl)-2, 5-diphenyl tetrazolium bromide (MTT), and Annexin V-FITC were purchased from HiMedia, Mumbai, India. All other reagents used were of analytical grade obtained from Merck Specialties Private Limited, Mumbai, India.

\section{Ethics statement}

All the experiments were conducted according to norms and guidelines of CPCSEA and Institutional Animal Ethical Committee (367001/C/ CPCSEA) of University. 
Plant material and extract preparation

The $C$. callosus fruits (15 kg) were collected and authenticated by M. S. Mondal, Botanical Survey of India, Kolkata, India, and the voucher specimen number was CNH/1-1(196)/2007/Tech-II/160. The methanol extract of the pericarp powder of dried fruits was prepared, and its yield was found to be $17.6 \% \mathrm{w} / \mathrm{w}$.

\section{Acute toxicity study}

The $\mathrm{LD}_{50}$ dose of the extract was determined by administering the extract orally to male Swiss albino mice [18].

\section{Assay for in vitro anticancer assay}

Cell culture

EAC cells were obtained from Chittaranjan National Cancer Institute (CNCI, Kolkata, India) for in vitro study. The EAC cells were maintained in vivo in Swiss albino mice by intraperitoneal transplantation of $2 \times 10^{6}$ cells per mouse after every 10 days at the Pharmacology Research Laboratory of KL Deemed to be University.

\section{Trypan blue exclusion assay}

At first, different concentrations of $\operatorname{MFCC}(0.35,0.45,0.55,0.65$, and $0.75) \mathrm{mg} / \mathrm{mL}$ and 5 -FU $(0.02,0.12,0.22,0.33$, and 0.44$) \mathrm{mg} / \mathrm{mL}$ were prepared. $1 \times 10^{6}$ EAC cells were suspended in $0.1 \mathrm{~mL}$ of phosphate buffered saline (PBS, $0.2 \mathrm{M}$, and $\mathrm{pH}$ 7.4) and mixed with $100 \mathrm{~mL}$ of various aforementioned concentrations of the drug. The final concentration of drug solution was adjusted by PBS and incubated at $37^{\circ} \mathrm{C}$ for $3 \mathrm{~h}$. After $3 \mathrm{~h}$, equal quality of the drug-treated cells is mixed with Trypan blue $(0.4 \%)$ and left for $1 \mathrm{~min}$. It is then loaded in a hemocytometer, and the viable and non-viable count is recorded within 2 min. Viable cells do not take up color, whereas dead cells take up the color. However, if kept longer, live cells also generate and take up the color [19].

The percentage of growth inhibition is calculated using the following formula:

Growth inhibition $(\%)=\frac{\text { Total cells }- \text { Dead cells }}{\text { Total cells }} \times 100$

\section{MTT assay}

The MTT assay was used for quantitative determination of viable cells. The assay was based on the conversion of the yellow tetrazolium saltMTT, to purple-formazan crystals by metabolically active cells. 96 well plates at a cell density of $2 \times 10^{6} / \mathrm{ml}$ per well in $100 \mu \mathrm{l}$ of RPMI 1640 were allowed to grow in a $\mathrm{CO}_{2}$ incubator for $24 \mathrm{~h}\left(37^{\circ} \mathrm{C}, 5 \% \mathrm{CO}_{2}\right)$. The medium is then removed and replaced by fresh medium containing different concentrations of MFCC and 5-FU for $48 \mathrm{~h}$. The cells are incubated for $24-48 \mathrm{~h}\left(37^{\circ} \mathrm{C}, 5 \% \mathrm{CO}_{2}\right)$. Then, $20 \mu \mathrm{l}$ MTT stock solutions ( $5 \mathrm{mg} / \mathrm{ml}$ in PBS) are added to each well and incubated for $5 \mathrm{~h}$. The medium is removed and $200 \mu \mathrm{l}$ dimethyl sulfoxide is added to each well to dissolve the MTT metabolic product. Then, the plate was shaken at $150 \mathrm{rpm}$ for $5 \mathrm{~min}$, and the optical density was measured at $560 \mathrm{~nm}$. Untreated cells (basal) are used as a control of viability (100\%), and the results are expressed as percentage viability (log) relative to the control [20].

$$
\% \text { viability }=\frac{O D \text { of test material }}{\text { OD of control }} \times 100
$$

$\%$ Inhibition $=100-(\%$ viability $)$

\section{Assay for in vivo anticancer assay} Transplantation of tumor

Ascitic fluid was drawn out from EAC tumor-bearing mouse. The viable EAC cells were counted (Trypan blue indicator) under the microscope and were adjusted at $2 \times 10^{7}$ cells $/ \mathrm{ml}$. All mice were injected with EAC cells suspension $(0.1 \mathrm{ml})$ (ip).
Treatment schedule

30 numbers of Swiss albino mice $(20-25 \mathrm{~g})$ were divided into five groups. Group I kept as normal saline control ( $5 \mathrm{ml} / \mathrm{kg}$ b.w, oral) and Group II kept as EAC control $\left(2 \times 10^{6}\right.$ cells/mouse, ip). After $24 \mathrm{~h}$ of EAC transplantation animals in Groups III and IV administered MFCC (350) and (450) mg/kg b.w, oral respectively; Group V administered 5 -FU (30 mg/kg b.w, oral) once daily for 9 consecutive days. After administration of the last dose, 6 mice from each group were kept fasting for $18 \mathrm{~h}$ and blood was collected by cardiac puncture for the estimation of hematological and biochemical parameters. Antitumor activity of MFCC was assessed by observation of changes with respect to the parameters as per Haldar et al. 2010 [13].

Evaluation of apoptosis using fluorescence-activated cell sorting (FACS)

To understand the nature of cell death, we utilized double labeling techniques using annexin-V-FITC/PI to distinguish between apoptotic and necrotic cells (Fig. 2).

\section{RESULTS}

\section{Acute toxicity study}

The $\mathrm{LD}_{50}$ dose of MFCC was found to be $3500 \mathrm{mg} / \mathrm{kg}$, b.w., p.o. in mice.

\section{In vitro anticancer assay}

The in vitro anticancer assay of the MFCC showed a direct cytotoxic effect in a dose-dependent manner. As the concentration of the drug increased, the cytotoxicity also increased. Average $50 \%$ of the cytotoxicity $\left(\mathrm{IG}_{50}\right)$ was observed at the concentration of $0.61 \mathrm{mg} / \mathrm{mL}$ for MFCC and $0.346 \mathrm{mg} / \mathrm{mL}$ for 5-FU (Fig. 3)

\section{In vivo anticancer assay}

Antitumor activity of MFCC and 5-FU against EAC tumor-bearing mice was assessed by tumor volume, tumor weight, cell count (viable and non-viable), mean survival time, and percentage increase in lifespan. The tumor volume, tumor weight, and viable cell count were found to be significantly increased, and non-viable cell count was significantly decreased in EAC control animals when compared with normal control animals (Table 1). Administration of MFCC at the doses of 350 and $450 \mathrm{mg} / \mathrm{kg}$ significantly decreased the tumor volume and viable cell count. Non-viable cell count was significantly higher in MFCC treated animals when compared with EAC control animals.

There was an increased level of white blood cell (WBC) and decreased the level of hemoglobin ( $\mathrm{Hb}$ ) and red blood cell (RBC) in EAC control group as compared to normal control group (Table 2). After treatment with MFCC at the doses of 350 and $450 \mathrm{mg} / \mathrm{kg}$ in EAC bearing mice significantly increased the RBC count, Hb content, and significantly reduced the WBC count as compared with the EAC control group.

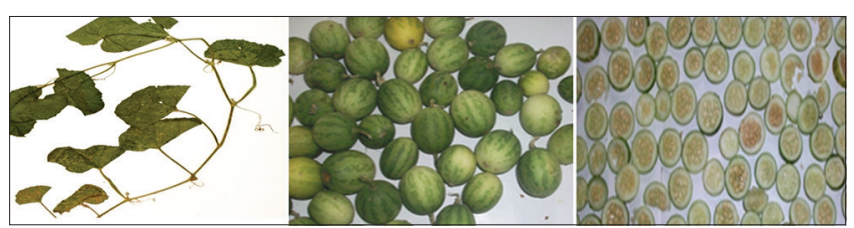

Fig. 1: Cucumis callosus herb, whole fruits, and their crosssectional parts

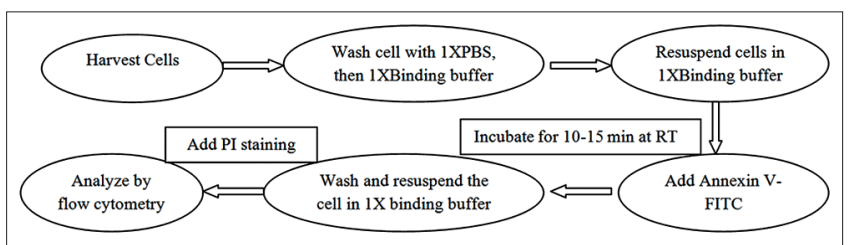

Fig. 2: Schematic representation of the Annexin-V FITC assay 
Table 1: Effect of MFCC on tumor volume, tumor weight, total cell count, viable and non-viable cell count, MST and \%ILS in EAC bearing mice

\begin{tabular}{lllll}
\hline Parameters & EAC control & EAC+MFCC $(\mathbf{3 5 0} \mathbf{~ m g} / \mathbf{k g})$ & EAC+MFCC $\mathbf{4 5 0} \mathbf{~ m g} / \mathbf{k g})$ & EAC+5-FU $(\mathbf{3 0} \mathbf{~ m g} / \mathbf{k g})$ \\
\hline Tumor volume $(\mathrm{ml})$ & $2.75 \pm 0.23$ & $1.72 \pm 0.16^{*}$ & $0.88 \pm 0.14^{*}$ & $0.65 \pm 0.15^{*}$ \\
Tumor weight $(\mathrm{g})$ & $3.16 \pm 0.14$ & $1.18 \pm 0.06^{\#}$ & $0.92 \pm 0.07^{*}$ & $0.61 \pm 0.03^{*}$ \\
Total cell $\left(\times 10^{7} \mathrm{cell} / \mathrm{ml}\right)$ & $9.20 \pm 0.43$ & $5.45 \pm 0.21^{*}$ & $3.70 \pm 0.15^{*}$ & $3.91 \pm 0.08^{*}$ \\
Viable cell $\left(\times 10^{7} \mathrm{cell} / \mathrm{ml}\right)$ & $8.92 \pm 0.42$ & $3.78 \pm 0.31^{*}$ & $1.04 \pm 0.08^{*}$ & $0.60 \pm 0.08^{*}$ \\
Non-viable cell $\left(\times 10^{7} \mathrm{cell} / \mathrm{ml}\right)$ & $0.27 \pm 0.03$ & $1.36 \pm 0.08^{*}$ & $2.65 \pm 0.07^{*}$ & $3.18 \pm 0.06^{*}$ \\
Viable cell $(\%)$ & 94.92 & 75.00 & 28.68 & 14.65 \\
Nonviable cell $(\%)$ & 4.07 & 26.00 & 74.43 & 85.25 \\
MST (days) & 18.00 & 27.50 & 33.00 & 38.00 \\
\hline
\end{tabular}

Values are mean \pm SE from 6 observations in each group. One-way ANOVA between EAC control group and treated groups followed by Dunnett's test. p: ${ }^{*}<0.05 ;{ }^{*}<0.01$. MST: Median survival time, \%ILS: Percentage increase life-span, MFCC: Methanolic fruit extract of Cucumius callosus, EAC: Ehrlich Ascites Carcinoma, SE: Standard error, ANOVA: Analysis of variance

Table 2: Effect of MFCC on hematological parameters in EAC bearing mice

\begin{tabular}{|c|c|c|c|c|c|}
\hline Parameters & Normal control & EAC control & EAC+MFCC (350 mg/kg) & EAC+MFCC (450 mg/kg) & $\mathrm{EAC}+5-\mathrm{FU}(30 \mathrm{mg} / \mathrm{kg})$ \\
\hline $\mathrm{RBC}\left(\right.$ cell $\left.\times 10^{6} / \mu \mathrm{l}\right)$ & $5.18 \pm 0.20$ & $2.83 \pm 0.13^{\mathrm{a}, *}$ & $4.04 \pm 0.24^{\mathrm{b}, \#}$ & $5.17 \pm 0.10^{\mathrm{b}, *}$ & $6.08 \pm 18^{\mathrm{b}, \#}$ \\
\hline WBC (cell× $\left.10^{3} / \mu \mathrm{l}\right)$ & $4.86 \pm 0.32$ & $7.87 \pm 0.65^{\mathrm{a}, *}$ & $6.12 \pm 0.23^{\mathrm{b}, \#}$ & $5.08 \pm 0.23^{\mathrm{b}, *}$ & $6.12 \pm 0.66^{\mathrm{b}, \#}$ \\
\hline Hemoglobin (g/dl) & $12.46 \pm 0.38$ & $4.60 \pm 0.28^{\mathrm{a}, *}$ & $8.19 \pm 0.43^{\mathrm{b}, \#}$ & $10.15 \pm 0.36^{\mathrm{b}, *}$ & $10.64 \pm 0.38^{\mathrm{b}, \#}$ \\
\hline
\end{tabular}

Values are mean \pm SE from 6 observations in each group. One-way ANOVA between EAC control group and the treated groups followed by Dunnett's test. ${ }^{a} \mathrm{EAC}$ control group versus normal group; treated groups versus EAC control group. p: ${ }^{*<0.05}$; $^{*}<0.01$. MFCC: Methanolic fruit extract of Cucumis callosus, EAC: Ehrlich Ascites Carcinoma, SE: Standard error, RBC: Red blood cell, WBC: White blood cell, ANOVA: Analysis of variance

\section{FACS}

Our flow cytometry data revealed that, in comparison with control untreated EAC cells (Fig. 4), MFCC at the doses of 350 and $450 \mathrm{mg} / \mathrm{kg}$ increases the apoptosis level by 12.7 and $14.8 \%$, respectively.

\section{Statistical analysis}

The data expressed as the mean \pm standard error were statistically analyzed using one-way ANOVA followed by Dunnett's post hoc test by GraphPad Prism software, version 5. $\mathrm{p}<0.05$ was considered significant and $\mathrm{p}<0.01$ as highly significant.

\section{DISCUSSION}

Our previous research evaluated hypoglycemic, antioxidant, and antihyperlipidemic potential of $C$. callosus fruit and also, proved that isolated $\mathrm{CuB}$ was the promising source for such activity [15,21]. It is well known that plants with antioxidant property can be effective for the treatment of cancer, liver damage, inflammation, etc. Hence, the effect of MFCC on EAC bearing mice satisfy the notion. It may be that the active phytoconstituent $\mathrm{CuB}$ reaches the target site. The plants with the genus Cucumis are found to be effective as anticancer agent only when they contain $\mathrm{CuB}$. Thus presence of $\mathrm{CuB}$ or ELP may also be the reason for the MFCC to exhibit anticancer effect against EAC bearing mice.

In EAC tumor-bearing mice, a regular rapid increase in ascitic tumor volume was observed. Ascitic fluid is the direct nutritional source for tumor cells, and a rapid increase in an ascitic fluid with tumor growth would be a means to meet the nutritional requirement of tumor cells [22]. 5-FU is a key anticancer drug, with a broadspectrum of activity against various forms of tumors (of the brain, breast, gastrointestinal tract, ovary, liver, pancreas, etc.), alone or in combination with other chemotherapeutic agents [23,24]. Treatment with MFCC and 5-FU decreased the tumor volume, tumor weight, and viable tumor cell count of the tumor-bearing mice. Usually, in cancer chemotherapy, the major problems that are being encountered are a reduction in RBC and WBC count in blood [25]. Treatment with MFCC and 5-FU brought back the RBC and WBC count toward the normal levels. Hence, that was clearly indicated the protective action of MFCC on the hemopoietic system.

Cucurbitacins are immensely bitter taste compound and are found in many plants belonging to Cucurbitaceae family. CuB, D, E, I, and their derivatives have been studied for their anticancer activities [26]. Miliato et al. 2012 demonstrated in vitro and in vivo anticancer properties of
Cucurbitacin isolated from Cayaponia racemosa [27]. The CuB exhibited strong cytotoxic effects against breast cancer cells in a dose-dependent manner and was shown to prominently alter the cytoskeletal network of breast cancer cells, inducing rapid morphological changes and improper polymerization of the microtubule network [28]. Furthermore, scientists discovered that $\mathrm{CuB}$ inhibited the tyrosine phosphorylation of STAT3, STAT5, and JAK2 in pancreatic cancer cell lines (Panc-1 and MiaPaCa-2) in vitro and in Panc-1 xenografts in vivo. Inhibition of the JAK-STAT pathway affected various downstream targets involved in progrowth signaling (e.g. c-myc, cyclins, and survivin) and apoptosis (e.g. p53, Bcl$\mathrm{xL}$, and Bcl-2) $[29,30]$. The cytotoxic effect of MFCC against EAC cells is probably due to downregulation of JAK and STAT proteins in EAC cells. The apoptotic mechanism was observed by cell cycle analysis using FACS.

In the early stages of apoptosis, the cell membrane is still intact and impermeable to DNA binding dye PI. However, Annexin-V binds specifically with phosphatidylserine is translocated to the extracellular leaflet of the membrane. In contrast, during necrosis, because the cell membrane is ruptured, these cells take up both the fluorochromes. The MFCC induced cell death observed in this study can occur by two distinct modes - apoptosis and necrosis, which can be distinguished by morphological and biochemical features. Annexin-V-FITC/PI staining of MFCC-treated EAT cells resulted in an increase in Annexin ${ }^{+} / \mathrm{PI}^{-}$and Annexin ${ }^{+} / \mathrm{PI}^{+}$cells compared to the control $\left(\right.$Annexin $\left.{ }^{-} / \mathrm{PI}^{-}\right)$, indicating apoptosis as a possible mode of cell death [31,32].

\section{CONCLUSION}

The present study demonstrates that the methanolic pericarp extract for C. callosus fruits has remarkable antitumor activity against Ehrlich's ascites carcinoma cells treated mice.

\section{ACKNOWLEDGMENTS}

We thank Dr. Pallab Kanti Haldar (Associate Professor) of Jadavpur University, Kolkata, for helpful comments on the manuscript and also thank to the authority of "KL Deemed to be University," for providing us all facility for successful completion of research work.

\section{AUTHOR'S CONTRIBUTION}

Conceived and designed the experiments: Siva Prasad Panda and Uttam Prasad Panigrahy. Performed the experiment: Siva Prasad Panda and A.R Reddy. Analyzed data: A.R Reddy and Uttam Prasad Panigrahy. All authors read and approved the final manuscript. 

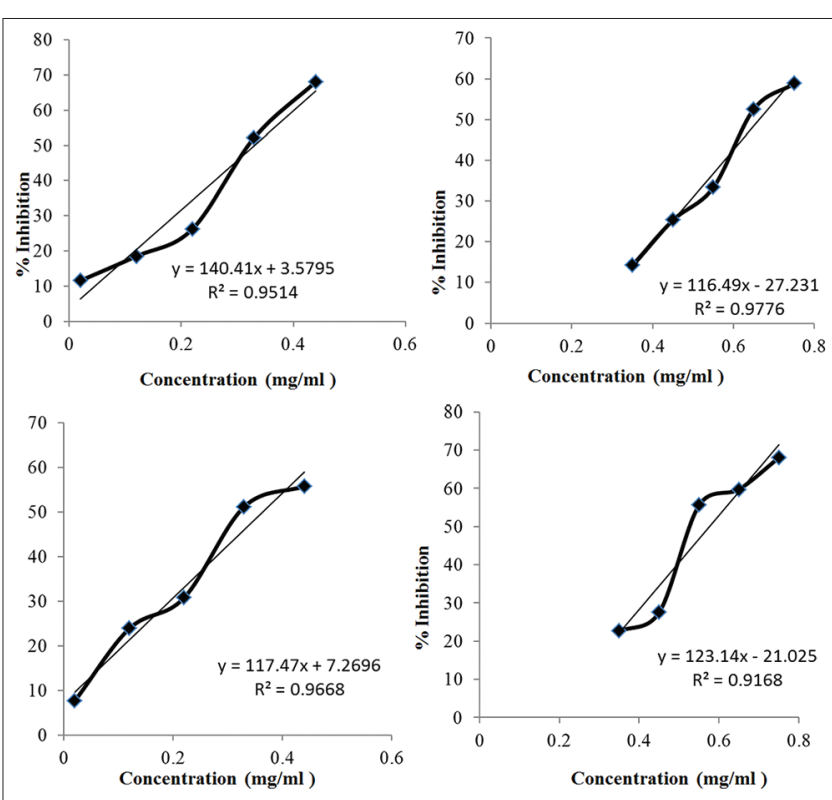

Fig. 3: Anticancer effect of methanolic fruit extract of Cucumis callosus and 5-FU on Ehrlich Ascites Carcinoma cell line by Trypan blue and 3-(4, 5-dimethylthiazol-yl)-2, 5-diphenyl tetrazolium bromide assay

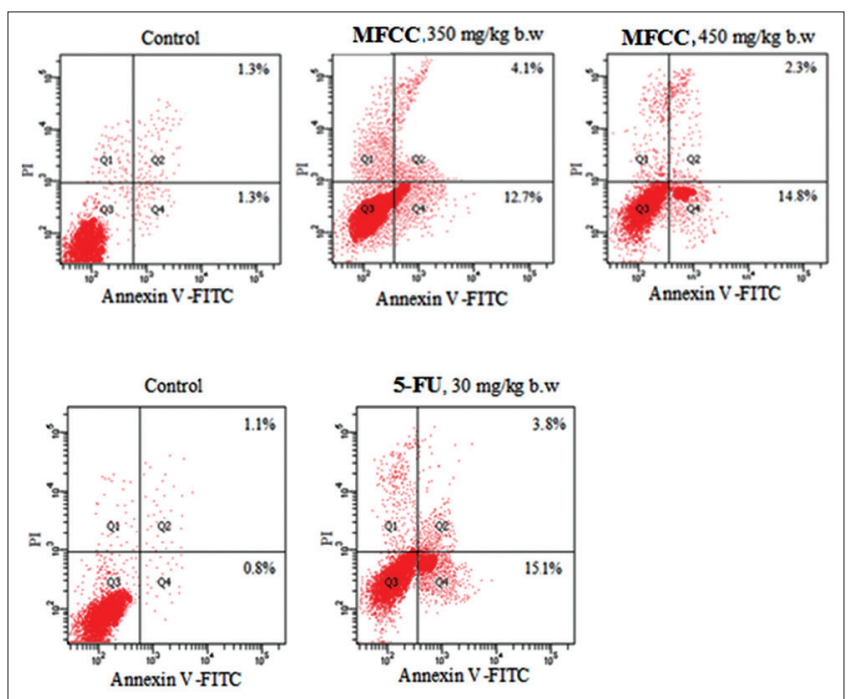

Fig. 4: Evaluation of percentage of apoptosis for methanolic fruit extract of Cucumis callosus and 5-FU

\section{CONFLICTS OF INTEREST}

The author declared that they have no conflicts of interest.

\section{REFERENCES}

1. Abdullaev FI, Luna RR, Roitenburd BV, Espinosa AJ. The pattern of childhood cancer mortality in Mexico. Arch Med Res 2000;31:526-31.

2. Hussain MA, Pati S, Swain S, Prusty M, Kadam S, Nayak S, et al. Pattern and trends of cancer in Odisha, India: A retrospective study. Asian Pac J Cancer Prev 2012;13:6333-6.

3. Abdullaev FI. In: Plant-derived Agents Against Cancer, Gupta SK, editors. Pharmacology and Therapeutics in the New Millennium. New Delhi: Narosa Publishing House; 2001. p. 345-54.

4. Patwardhan $\mathrm{B}$, Vaidya $\mathrm{AD}$, Chorghade M. Ayurveda and natural products drug discovery. Curr Sci 2004;86:6.

5. Diwanay S, Gautam M, Patwardhan B. Cytoprotection and immunomodulation in cancer therapy. Curr Med Chem Anticancer Agents 2004:4:479-90.
6. Tripathy KD. Anticancer drugs. Essential Medical Pharmacology. $6^{\text {th }}$ ed. New Delhi: Jaypee Brother's Medical Publishers (P) Ltd.; 2007. p. 820.

7. Ramos AA, Prata-Sena M, Castro-Carvalho B, Dethoup T, Buttachon S, Kijjoa A, et al. Potential of four marine-derived fungi extracts as ant proliferative and cell death-inducing agents in seven human cancer cell lines. Asian Pac J of Trop Med 2015;8:798-806.

8. Bhattaram VA, Graefe U, Kohler C, Veit M, Derendorf $\mathrm{H}$. Pharmacokinetic and bioavailability of herbal medicinal products. Phytomedicine 2002;9:1-33.

9. Hung HC, Joshipura KJ, Jiang R, Hu FB, Hunter D, Smith-Warner SA, et al. Fruit and vegetable intake and risk of major chronic disease. J Natl Cancer Inst 2004;96:1577-84.

10. Rathore M. Nutrient content of important fruit trees from arid zone of Rajasthan. J Hortic For 2009;1:103-8.

11. Raut M. Glimpses of Nature Series (No. 4) our Monsoon Plants, Bombay Natural History Society. Bombay, India; 1959.

12. Trivedi PC. Medicinal plants: Traditional knowledge. In: Sharma UK, Gogoi J, editors. Ethno-Medico-Botany of some Sacred Plants of Dhemaji District of Assam. New Delhi: IK International Pvt. Ltd.; 2006. p. 102

13. Haldar PK, Kar B, Bala A, Bhattacharya S, Mazumder UK. Antitumor activity of Sansevieria roxburghiana rhizome against Ehrlich ascites carcinoma in mice. Pharm Biol 2010;48:1337-43.

14. Islam K, Ali SM, Jesmin M, Khanam JA. In vivo teratogenic effect of the mixture using the Zebrafish embryo developmental assay. Cancer Biol Med 2012;9:242-7.

15. Panda SP, Sarangi AK, Panigrahy UP. Isolation of cucurbitacin-B from Cucumis callosus and its hypoglycemic effect in isolated rat enterocytes. Int J Pharm Pharm Sci 2018;10:123-9.

16. Kausar H, Munagala R, Bansal SS, Aqil F, Vadhanam MV, Gupta RC, et al. Cucurbitacin B potently suppresses non-small-cell lung cancer growth: Identification of intracellular thiols as critical targets. Cancer Lett 2013;332:35-45

17. Guo J, Wu G, Bao J, Hao W, Lu J, Chen X, et al. Cucurbitacin B induced ATM-mediated DNA damage causes G2/M cell cycle arrest in a ROS-dependent manner. PLoS One 2014;9:e88140.

18. Panda SP, Haldar PK, Bera S, Adhikary S, Kandar CC. Antidiabetic and antioxidant activity of Swietenia mahagoni in streptozotocin-induced diabetic rats. Pharm Biol 2010;48:974-9.

19. Bala A, Kara B, Haldar P, Mazumder U, Bera S. Evaluation of anticancer activity of Cleome gynandra on Ehrlich's ascites carcinoma treated mice. J Ethnopharmacol 2010;129:131-4.

20. Mossman T. Rapid colorimetric assay for cellular growth and survival: Application to proliferation and cytotoxicity assays. J Immunol Methods 1983;65:55-63.

21. Panda SP, Chakraborty M, Majumder P, Mazumder S, Das S, Haldar PK. The antidiabetic, antioxidant and anti-hyperlipidemic activity of Cucumis callosus in streptozotocin-induced diabetic rats. Int J Pharm Sci Res 2016;7:1978-84.

22. Prasad SB, Giri A. Antitumor effect of cisplatin against murine ascites dalton's lymphoma. Indian J Exp Biol 1994;32:155-62.

23. Arias JL. Novel strategies to improve the anticancer action of 5-fluorouracil by using drug delivery systems. Molecules 2008;13:2340-69.

24. Miura K, Kinouchi M, Ishida K, Fujibuchi W, Naitoh T, Ogawa H, et al 5-FU metabolism in cancer and orally-administrable 5-FU drugs. Cancers (Basel) 2010;2:1717-30.

25. Rajeshwar Y, Gupta M, Mazumder UK. Antitumor activity and in vivo antioxidant status of Mucuna pruriens (Fabaceae) seeds against Ehrlich ascites carcinoma in Swiss albino mice. Iranian J Pharmacol Ther 2005;4:46.

26. Chen JC, Chiu MH, Nie RL, Cordell GA, Qiu SX. Cucurbitacins and cucurbitane glycosides: Structures and biological activities. Nat Prod Rep 2005;22:386-99.

27. Militao GC, Dantas IN, Ferreira PM, Alves AP, Chaves DC, Monte FJ, et al. In vitro and in vivo anticancer properties of cucurbitacin isolated from Cayaponia racemose. Pharma Biol 2012;50:1479-87.

28. Duangmano S, Sae-Lim P, Suksamrarn A, Domann FE, Patmasiriwat P. Cucurbitacin B inhibits human breast cancer cell proliferation through disruption of microtubule polymerization and nucleophosmin/B23 translocation. BMC Complement Altern Med 2012;12:185.

29. Thoennissen NH, Iwanski GB, Doan NB, Okamoto R, Lin P, Abbassi S, et al. Cucurbitacin B induces apoptosis by inhibition of the JAK/STAT pathway and potentiates cytotoxic effects of gemcitabine on pancreatic cancer cells. Cancer Res 2009;69:5876-84.

30. Brantley EC, Benveniste EN. STAT-3: A molecular hub for signaling 
pathways in gliomas. Mol Cancer Res 2008;6:5.

31. Mukherjee C, Paul S, Kundu R. Comparative evaluation of ant proliferative activity of Solanum nigrum methanolic and aqueous extract on HELA, SIHA and C33A cells. Int J Pharm Pharm Sci
$2015 ; 7: 320-4$

32. Kumar Y, Periyasamy L. GC-MS analysis and in-vitro cytotoxic studies of Bixa orellana seed extract against cancer cell line. Int J Pharm Pharm Sci 2016;8:408-13 